\title{
Structure and Regeneration Status of Gedo Dry Evergreen Montane Forest, West Shewa Zone of Oromia National Regional State, Central Ethiopia
}

\author{
Birhanu Kebede $^{1^{\star}}$, Teshome Soromessa ${ }^{2}$ and Ensermu Kelbessa ${ }^{3}$ \\ ${ }^{1}$ Department of Biology, Ambo University, Post Box No: 19, Ambo, Ethiopia \\ ${ }^{2,3}$ Addis Ababa University, Post Box No: 1176, Addis Ababa, Ethiopia
}

\begin{abstract}
This study was conducted on Gedo Dry Evergreen Montane Forest in West Shewa Zone of Oromia National Regional State, 182-196 km west of Addis Ababa (Finfinne). The objective of the study was to determine structure and regeneration status of Gedo Forest. All trees and shrubs with Diameter at Breast Height $(\mathrm{DBH}) \geq 2 \mathrm{~cm}$ were measured for height and diameter. The density of tree species in Gedo Forest decreases with increasing height and $\mathrm{DBH}$ classes. The forest is characterized by high density of trees in the lower class than in the higher. Three layers (lower, middle and upper) of tree were identified from the study of vertical stratification of Gedo Forest following the International Union for Forestry Research Organization (IUFRO) classification scheme. The regeneration status of selected woody species was assessed as well as the forest was compared with five dry evergreen forests of Ethiopia. Based on the result of the study, research on the soil seed bank, population dynamics and ecology of endemic species were recommended.
\end{abstract}

Copyright@2014 STAR Journal. All Rights Reserved.

\author{
Article Information \\ Article History: \\ Received : 23-02-2014 \\ Revised : 02-06-2014 \\ Accepted : 17-06-2014 \\ Keywords: \\ Dry evergreen montane forest \\ Gedo Forest \\ Phytogeographical \\ Comparison

\section{${ }^{*}$ Corresponding Author:} \\ Birhanu Kebede \\ E-mail: \\ bkebede2020@gmail.com
}

\section{INTRODUCTION}

Ethiopia is an important regional center for biological diversity due to its wide ranges of altitude, its great geographical diversity with high and rugged mountains, flat-topped plateaus and deep gorges, incised river valleys and rolling plains (Ensermu Kelbessa et al., 1992; Zerihun Woldu, 1999). These helped the emergence of wide ranges of habitats that are suitable for the evolution and survival of various plant and animal species. As a result, the country is regarded as one of the most important countries in Africa with respect to endemism of plant and animal species in tropical Africa (EFAP, 1994; EWNHS, 1996). The country possesses about 6000 species of higher plants, of which about $10 \%$ are endemic (Ensermu Kelbessa, pers.Comm.).

A substantial proportion of the Ethiopian highlands were once believed to have been covered by forests having wide coverage than at present, but have gradually been cleared (Friis, 1992). Tamrat Bekele (1993) remarked that the occurrence of isolated mature trees in farmlands and the patches of forests that are seen around church-yards and religious burial grounds indicate the presence of vast expanse of forests earlier. At the moment, most of the remaining forests of the country are confined to south and south-western parts of the country; however, nowadays the remnant forests in these areas are threatened by human activities (Tamrat Bekele, 1994).

Historical document indicated that Ethiopia had experienced substantial deforestation, soil degradation and an increase in the area of bare land over the years. The need for fuel wood, arable land and grazing areas have been indicated as the main causes of forest degradation; frequently leading to loss of forest cover and biodiversity, erosion, desertification and reduced water resources (Ensermu Kelbessa and Teshome Soromessa, 2008). Deliberate fire and non-integrated investment activities are also reasons for the reduction of forests in Ethiopia. The high level of dependency of the local community on agriculture (more than 90\%) and high rate of population growth (EFAP, 1994; Tadesse Woldemariam, 2003; Simon Shibru and Girma Balcha, 2004; Feyera Senbeta, 2006) have also accelerated the problems. Various studies have indicated the intractable loss of forests in Ethiopia, among other, Teshome Soromessa et al. (2004); Ensermu Kelbessa and Teshome Soromessa (2008); Teshome Soromessa et al. (2011); Fekadu Gurmessa et al. (2011 and 2012); Adugna Feyissa et. al. (2013); Teshome Soromessa (2013); Teshome Soromessa and Ensermu Kelbessa (2013a and 2013b); Teshome Soromessa and Ensermu Kelbessa (2014); Mohammed Gedefaw et al. (2014) are the ones to mention.

Gedo Forest is a dry evergreen montane forest that is found in the high lands of Shewa. It is one of National Forest PriorityAreas with an area of about 10, 000 hectares (EFAP, 1994). Although Gedo State Forest is one of the 58 Regional Forest priority areas for conservation, it received little attention up to now. Information on vegetation is required to solve an ecological problem: for biological conservation and management purposes; as an input to environmental impact statements; to monitor management practices or to 
Birhanu Kebede et al.,

provide the basis for prediction of possible future changes.

Forests can be seen as an earth's lungs. They play a crucial role in tempering the effects of climate and help protect vital water catchments. Trees provide a wide range of products, including food and fruit, timber, fodder for livestock, habitat for wildlife and medicines for both people and livestock. Forests supply goods of commercial, cultural, and sacred value, and used as several raw materials, which are primarily used in woodbased industries and they comprise a vital safety net in times of need.

Gedo Forest is one of the forests that have been providing the above uses. However, because of its accessibility, the vegetation has been severely and unwisely exploited. Consequently, the existing conditions call for a critical mitigating means. The vegetation of this area was intact previously (information from community elders) but highly depleted at present. It has also not been studied before and hence, the need to
Sci. Technol. Arts Res. J., April-June 2014, 3(2):119-131

gather information on the ecology and regeneration status of the forest is very important. Without a full assessment of the properties of the various sites in a forest and their relation to vegetation growth, the management of the forest will be severely handicapped. The main objective of the research was to determine structural and regeneration status of Gedo Forest.

\section{MATERIALS AND METHODS}

Description of the Study Area

Geographical Location

Gedo Forest is located in Cheliya District, West Shewa Zone of Oromia National Regional State (Figure 1). The northwestern part of the District is covered with hilly slopes and mountainous escarpments rising to an elevation of about 3060 m.a.s.l at Tullu Jarso Mountain (Endalew Amenu, 2007). The study area District lies approximately between latitudes $9^{0} 02^{\prime}$ and $9^{\circ} 01^{\wedge}$ North and longitudes $37^{\circ} 25^{`}$ and $37^{\circ} 16^{`}$ East.

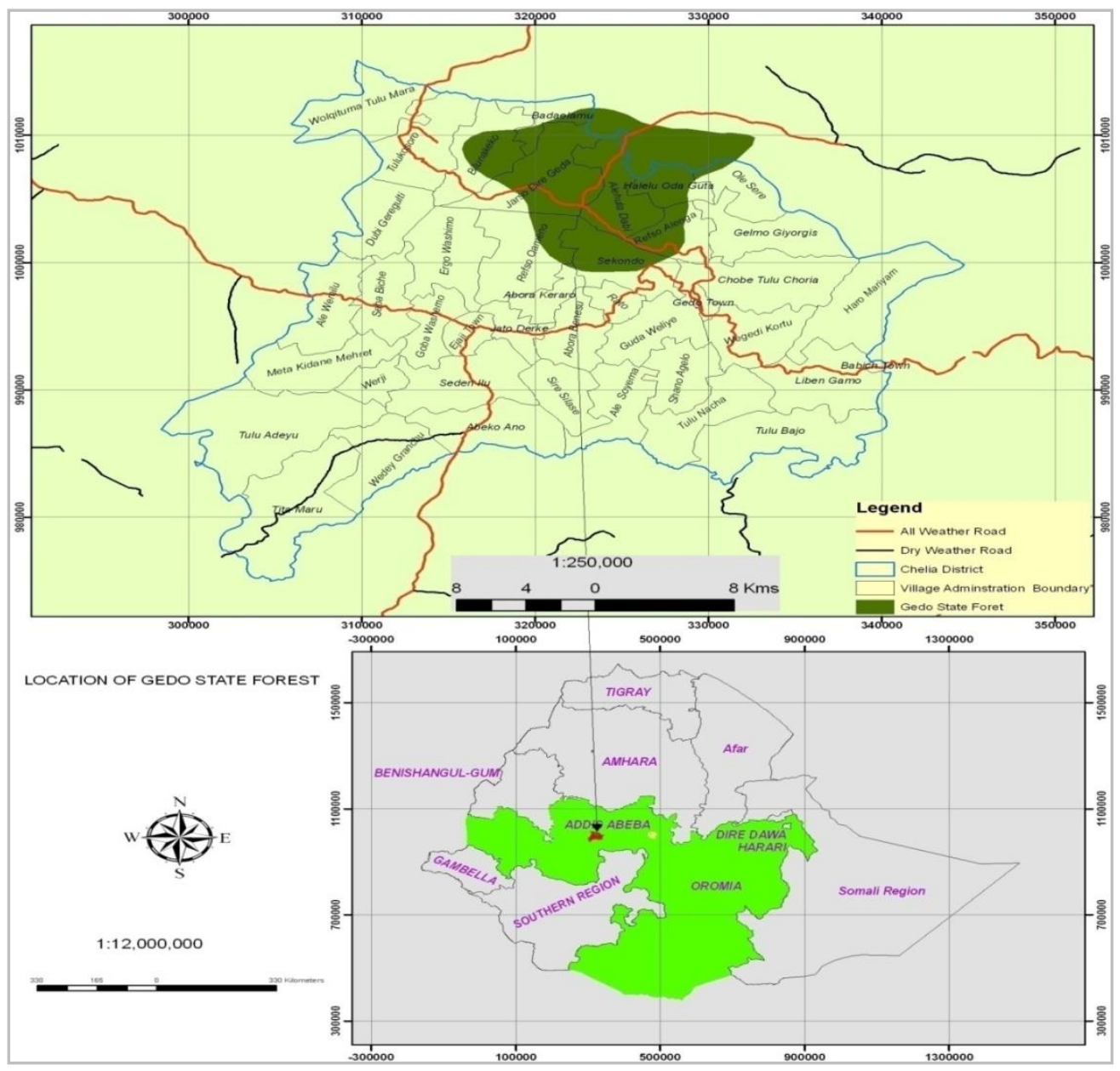

Figure 1: Map of Ethiopia and the study area

\section{Climate}

Meteorological data obtained from National Meteorology Service Agency (Addis Ababa) indicates that Gedo area obtains high rainfall between May to September and low rainfall from December to February (Figure 2). The highest mean annual rainfall of the study area within ten years (2000-2009) was $186.4 \mathrm{~mm}$ recorded in July followed by $183.2 \mathrm{~mm}$ in August whereas the lowest mean annual rainfall was $15.1 \mathrm{~mm}$ recorded in December. The rainfall distribution increases from midFebruary to mid-March then decrease slightly in mid-April. From mid-April to mid-September the amount of rainfall is high. The lowest mean temperature over ten years was $8.7^{\circ} \mathrm{C}$ recorded in December, whereas the highest was $24.6^{\circ} \mathrm{C}$ recorded in February. 


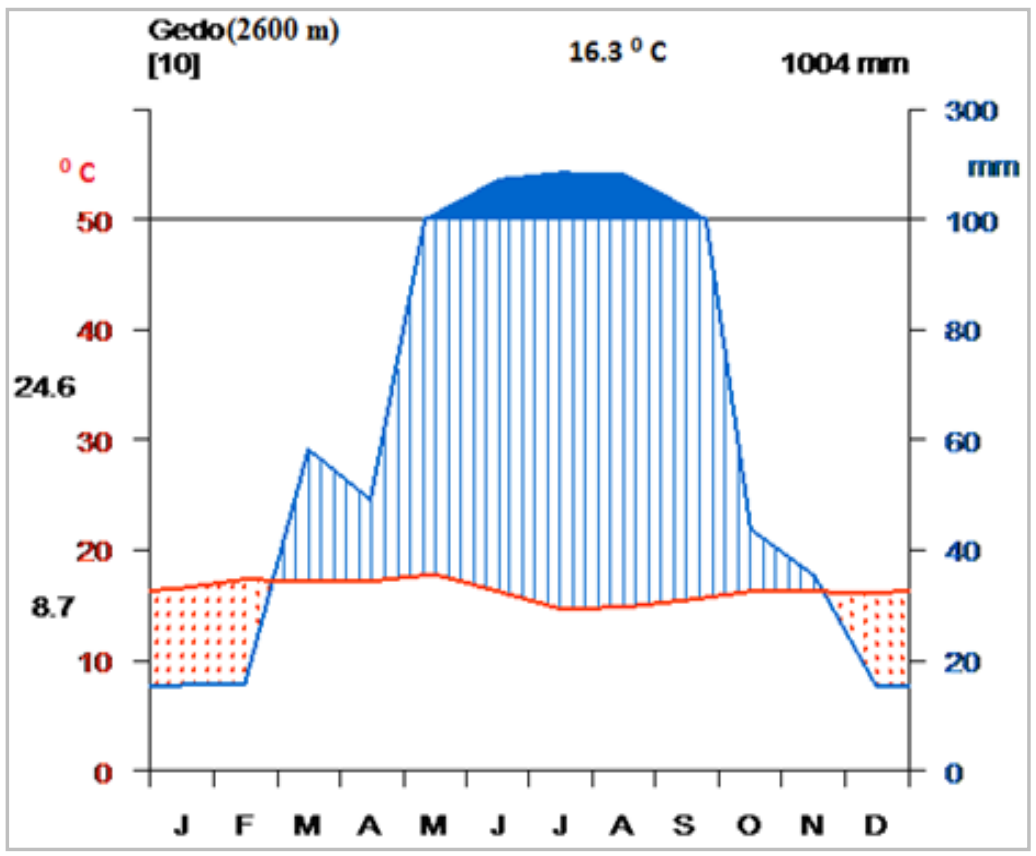

Figure 2: Climadiagram showing rainfall distribution and temperature variation from 2000-2009 at Gedo Station.

(Source: Data obtained from National Meteorological Service Agency (2010))

\section{MATERIALS AND METHODS}

\section{Data Collection}

\section{Sampling Design}

Vegetation data were collected from sample plots placed in transect lines, which are systematically laid. A total of 72 plots were laid along transect lines following the Braun-Blanquet approach of phytosociology as modified by van der Maarel (1979). Quaqrats of $20 \mathrm{~m}$ x $20 \mathrm{~m}(400$ $\mathrm{m}^{2}$ ) were laid at every 200 meters along 12 transect lines, which are laid 300 meters apart. Transects are used because they are considerable importance in the description of vegetative change along an environmental gradient, or in relation to some marked feature of topography.

\section{Floristic Data Collection}

All plant species of shrubs and trees in each quadrat were recorded. Additional woody species occurring outside quadrats, but inside the forest were also recorded only as 'present', but they were not used in the subsequent data analysis. The vernacular (local) names were used when available. In the study area, physiographic variables such as altitude, longitude, latitude and aspect were measured for each quadrat using altimeter, GPS, and compass respectively. The plant specimens collected were brought to the National Herbarium (ETH) of Addis Ababa University for identification. The specimens were dried in the dryer, kept in a deep freezer for 72 hours and identified referring to the volumes of Flora of Ethiopia and Eritrea, consulting experts and lastly using authenticated specimens at the Herbarium and finally deposited there with their labels.

\section{Structural Data Collection}

Each individual of the woody species was counted, circumference at breast height, i.e. $1.3 \mathrm{~m}$, of all trees and shrubs having circumference greater than $6 \mathrm{~cm}(\mathrm{DBH}$ greater than $2 \mathrm{~cm}$ ) were measured and later it was changed in to diameter and the heights of tree and shrub species above $2 \mathrm{~m}$ were visually estimated and recorded and later grouped into height classes. For the purpose of the study "seedlings", "saplings" and "mature trees/ shrubs" were defined as plants with heights less than $1 \mathrm{~m}$, 1-3 $\mathrm{m}$ and greater than $3 \mathrm{~m}$ respectively. Percentage cover abundance was estimated and later converted into modified Braun Blanquet scale. The 1-9 modified BraunBlanquet scale was used following van der Maarel (1979).

\section{Structural Data Analysis}

All individuals of species recorded in all the 72 quadrats were used in the analysis of vegetation structure. The Diameter at Breast Height $(\mathrm{DBH})$, basal area, tree density, height, frequency and important value index were used for description of vegetation structure.

Importance Value Index (IVI): is useful to compare the ecological significance of species. It combines data for three parameters (relative frequency, relative density and relative abundance) or it often reflects the extent of the dominance, occurrence and abundance of a given species in relation to other associated species in an area (Kent and Coker, 1992).

Importance value index (IVI) $=\mathrm{RD}+\mathrm{RF}+\mathrm{RDO}$

Where, RD is Relative Density, RF is Relative Frequency, and RDO is Relative Dominance.

Height: is a straight forward parameter used for direct measurement purposes. The Tree height was also classified into ten classes (3-6 m, 6-9 m, 9-12 m, 12-15 $\mathrm{m}, 15-18 \mathrm{~m}, 18-21 \mathrm{~m}, 21-24 \mathrm{~m}, 24-27 \mathrm{~m},>27 \mathrm{~m})$.

\section{RESULTS AND DISCUSSION Vegetation Structure Tree Density}

The density of tree individuals of Gedo Forest with $\mathrm{DBH}$ greater than 2, 10, and $20 \mathrm{~cm}$ was shown. The Density of trees with $\mathrm{DBH}$ greater than $2 \mathrm{~cm}$ in the study area is $781.94 /$ ha. The number of stems with $\mathrm{DBH}>10 \mathrm{~cm}$ was found to be 832 and those with $\mathrm{DBH}>20 \mathrm{~cm}$ was 464. The ratio of $\mathrm{DBH}>10 \mathrm{~cm}$ to $\mathrm{DBH}>20 \mathrm{~cm}$ is high 
(1.79). The ratio of tree density $>10 \mathrm{~cm} \mathrm{DBH}$ to $>20 \mathrm{~cm}$ $\mathrm{DBH}$ is taken as a measure of the size classes (Grubb et al., 1963). Therefore, the $\mathrm{a} / \mathrm{b}$ ratio in Gedo Forest indicates the predominance of small sized tree individuals which indicates the forest was under heavy degradation and in a stage of secondary development.
Tree densities with $\mathrm{DBH}$ greater than 10 and $20 \mathrm{~cm}$ in Gedo Forest were compared with that of fourteen different forests in Ethiopia (Table 1). The ratio of tree densities with $\mathrm{DBH}>10 \mathrm{~cm}$ to tree densities $>20 \mathrm{~cm}$ is also included in the comparison.

Table 1: Comparison of tree densities with $\mathrm{DBH}$ between 10 and 20, and $>20 \mathrm{~cm}$ from Gedo forest with other forests in Ethiopia arranged in increasing order of $X / Y$.

\begin{tabular}{|c|c|c|c|c|}
\hline Forest & $10<\mathrm{DBH}>20(X)$ & $\mathrm{DBH}>\mathbf{2 0}(\mathrm{Y})$ & $\mathbf{X} / \mathbf{Y}$ & Forest types \\
\hline Egdu (MAM) $^{11}$ & 155 & 197 & 0.8 & Dry Afromontane \\
\hline Wof-Washa ${ }^{1}$ & 329 & 215 & 1.5 & Dry Afromontane \\
\hline Dodola $^{3}$ & 521 & 351 & 1.5 & Dry Afromontane \\
\hline Alata- Bolale ${ }^{10}$ & 365 & 219 & 1.7 & Moist Afromontane \\
\hline Gedo $^{12}$ & 832 & 464 & 1.79 & Dry Afromontane \\
\hline Magada $^{5}$ & 608 & 332 & 1.8 & Dry Afromontane \\
\hline $\operatorname{Jima}^{9}$ & 335 & 184 & 1.8 & Moist Afromontane \\
\hline Denkoro $^{6}$ & 526 & 285 & 1.9 & Dry Afromontane \\
\hline Bibita $^{7}$ & 500 & 265.6 & 1.9 & Moist Afromontane \\
\hline Dindin $^{4}$ & 437 & 219 & 1.99 & Dry Afromontane \\
\hline Jibat $^{1}$ & 565 & 287 & 2 & Humid Afromontane \\
\hline Menna Angetu ${ }^{8}$ & 292.59 & 139.78 & 2.08 & Moist Afromontane \\
\hline Menagesha $^{1}$ & 484 & 208 & 2.3 & Dry Afromontane \\
\hline Masha Anderacha $^{2}$ & 385.7 & 160.5 & 2.4 & Moist Afromontane \\
\hline Chilimo $^{1}$ & 638 & 250 & 2.6 & Dry Afromontane \\
\hline
\end{tabular}

Source: Tamrat Bekele (1993), ${ }^{2}$ Kumelachew Yeshitela and Taye Bekele (2003), ${ }^{3}$ Kitessa Hundera (2003), ${ }^{4}$ Simon Shibru and Girma Balcha (2004), ${ }^{5}$ Genene Bekele (2005), ${ }^{6}$ Abate Ayalew et al., (2006), ${ }^{7}$ Dereje Denu (2007), ${ }^{8}$ Ermias Lulekal et al., (2008),

${ }^{9}$ Fufa Kenea (2008), ${ }^{10}$ Woldeyohannes Enkossa (2008), ${ }^{11}$ Abiyou Tilahun (2009), ${ }^{12}$ Birhanu Kebede (Present study).

In this comparison, the ratio of tree densities with $\mathrm{DBH}$ $10<\mathrm{DBH}<20 \mathrm{~cm}$ to density $>20 \mathrm{~cm}$ in Gedo Forest showed that there is very close similarity with Jima and Magada Forests and has close similarity to Dindin, Denkoro and Bibita forests. The ratio $a / b$ indicated that Gedo Forest has more trees in the lower DBH classes than in the higher classes when compared to Wof Washa, Dodolla, Alata- Bolale and Egdu (Menagesha Amba Mariam) forests. Five forests in the comparison (Jibat, Menagesha, Chilimo, Mena Angetu, and Masha Anderacha) have more $\mathrm{a} / \mathrm{b}$ ratio values than Gedo Forest indicating that there are more predominance of trees in the lower DBH class in these forests than in Gedo Forest although the recent study and the present status of some of the forests are not well known. The reason behind these are geographical location, the nature of the forest (whether it is moist or dry), altitudinal variation, age of the forest, degree of conservation and exposure to disturbance.

\section{Diameter at Breast Height (DBH)}

The distribution of trees in different $\mathrm{DBH}$ classes is given in Table 2 with their percentages and density per hectare.

Table 2: Distribution of DBH classes.

\begin{tabular}{cccc}
\hline DBH class & Density & Density ha $^{-1}$ & $\%$ \\
\hline $2-8$ & 761 & 264.24 & 33.79 \\
$8-14$ & 654 & 227.08 & 29.04 \\
$14-20$ & 373 & 129.51 & 16.56 \\
$20-26$ & 143 & 49.65 & 6.35 \\
$26-32$ & 93 & 32.29 & 4.13 \\
$32-38$ & 48 & 16.67 & 2.13 \\
$38-44$ & 61 & 21.18 & 2.71 \\
$44-50$ & 35 & 12.15 & 1.56 \\
$50-56$ & 18 & 6.25 & 0.78 \\
$>56$ & 55 & 19.09 & 2.44 \\
\hline $1(2-8 \mathrm{~cm}), 2(8-14 \mathrm{~cm}), 3(14-20 \mathrm{~cm}), 4(20-26 \mathrm{~cm}), 5(26-32 \mathrm{~cm})$, \\
$6(32-38 \mathrm{~cm}), 7(38-44 \mathrm{~cm}), 8(44-50 \mathrm{~cm}), 9(50-56) 10(>56)$
\end{tabular}

Distribution of all individuals in different $\mathrm{DBH}$ size classes showed an inverted J-shaped distribution. This pattern indicates that the majority of the species had the highest number of individuals in lower $\mathrm{DBH}$ which in turn shows that the forest vegetation has good reproduction and recruitment potential. Similar results were reported by Kumelachew Yeshitela and Taye Bekele (2003); Abate
Ayalew et al. (2006); Feyera Senbeta (2006); Woldeyohannes Enkossa (2008).

Gedo Forest is similar to Bibita and Menna Angetu Forests in the number of individuals of woody species in lower DBH class (I and II) and lower than the rest of the forests under comparison. The percent of trees in $\mathrm{DBH}$ 
Birhanu Kebede et al.,

class III in Gedo Forest is similar to that of Chilimo Forest and but lower than the others. The percentage of trees in DBH class $V$ in Gedo Forest is lower than in Magada, Bibita and Mena Angetu and higher than the rest of the forests under comparisons. The percentage of trees in $\mathrm{DBH}$ class VI in Gedo Forest is greater than that of
Sci. Technol. Arts Res. J., April-June 2014, 3(2):119-131

Menagesha, Wof-Washa, and Chilimo and less than the other forests in the comparison. Therefore Gedo Forest is higher than the Dry Afromontane Forests of the central Shewa in higher DBH classes i.e. it has more mature tree species.

Table 3: Comparison of Gedo Forest with other seven forests in Ethiopia regarding percentage distribution of tree species in different DBH classes $(I=10-20 \mathrm{~cm}, I I=20-50 \mathrm{~cm}, \mathrm{III}=50-80 \mathrm{~cm}, \mathrm{IV}=80-110 \mathrm{~cm}, \mathrm{~V}=110-140$ $\mathrm{cm}, \mathrm{VI}=>140 \mathrm{~cm})$

\begin{tabular}{lcccccc}
\hline \multirow{2}{*}{ Forest } & \multicolumn{7}{c}{ DBH classes } \\
\cline { 2 - 7 } & I & II & III & IV & V & VI \\
\hline Menagesha1 & 56.9 & 32.8 & 06.5 & 02.5 & 0.00 & 0.00 \\
Wof-Washa $^{1}$ & 32.6 & 31.7 & 14.6 & 17.7 & 0.00 & 0.00 \\
Chilimo $^{1}$ & 60.08 & 36.5 & 02.6 & 0.00 & 0.00 & 0.00 \\
Magada $^{2}$ & 45.4 & 44.1 & 06.3 & 02.6 & 1.0 & 0.7 \\
Denkoro $^{3}$ & 46.0 & 46.0 & 06.3 & 01.1 & 0.2 & 0.4 \\
Bibita $^{4}$ & 30.2 & 24.4 & 06.2 & 01.7 & 0.5 & 1.4 \\
Mena Angetu $^{5}$ & 32.0 & 25.5 & 08.9 & 02.4 & 0.7 & 1.1 \\
Gedo $^{6}$ & 36.94 & 16.92 & 02.53 & 0.49 & 0.36 & 0.31 \\
\hline
\end{tabular}

Source: 'Tamrat Bekele (1993), ${ }^{2}$ Genene Bekele (2005), ${ }^{3}$ Abate Ayalew et al. (2006),

${ }^{4}$ Dereje Denu (2007), ${ }^{5}$ Ermias Lulekal et al., (2008), ${ }^{6}$ Birhanu Kebede (Present study).

\section{Tree Height}

The trees in the study area could be conveniently divided into 9 height classes.

Table 4: Percentage distribution of trees in height classes in $\mathrm{m}$.

\begin{tabular}{ccc}
\hline Height class & Density ha $^{-1}$ & Percentage \\
\hline $3-6$ & 308.68 & 39.47 \\
$6-9$ & 311.81 & 39.87 \\
$9-12$ & 90.63 & 11.59 \\
$12-15$ & 28.82 & 3.69 \\
$15-18$ & 15.63 & 2.00 \\
$18-21$ & 11.81 & 1.51 \\
$21-24$ & 5.90 & 0.75 \\
$24-27$ & 4.86 & 0.62 \\
$>27$ & 3.82 & 0.49
\end{tabular}

Class I (3-6 m), II (6-9 m), III (9-12 m), 3 (12-15 m), IV (15- $18 \mathrm{~m})$, V $(18-21 \mathrm{~m}), \mathrm{VI}(21-24 \mathrm{~m})$, VII $(24-27 \mathrm{~m})$, VIII $(>27 \mathrm{~m})$

The density of trees decreased with increasing height classes (Table 4). This means, there are higher number of individuals in the lower size and a gradual decrease towards the middle and upper size trees indicating continuous representation of individuals in all height classes. The highest number of individual trees was found to be $308.68 \mathrm{ha}^{-1}$ representing the height class I. Trees in height class I and II have almost equal individuals and together make $79.34 \%$. Trees in the height classes III and IV together are found to be $15.28 \%$. Height can be used as an indicator of age of the forest. The old trees are found in the height class above $24 \mathrm{~m}$ and their percentage distribution is $1.11 \%$.

The height class I (6-9) of the Dry Afromontane Forests of the forests in Table 11 (Chilimo, Menagesha, Wof-Washa and Denkoro) is almost similar to Gedo Forest which is also Dry Afromontane but different from Jibat Forest which is the Humid Afromontane Forest. Gedo Forest has similar percent of individuals with Menagesha in class VI, with Denkoro and Menagesha in class VII and with Denkoro and Chilimo in IX. But less value than all except Menagesha in class III and less value than all in class IV showing less number of individuals in medium height of the tree species than the forests under comparisons which shows selective cutting of individuals at some stage of the plant.

Table 5: Height class $(\mathrm{m})$ Percentage distribution of trees in some Afromontane forests of Ethiopia taking class I (6-9), class II (9-12), class III (12-15) class IV (15-18), class V (18-21), class VI (21-24), class VII (24-27), class VIII $(27-30)$ and class IX $(>30)$.

\begin{tabular}{ccccccc}
\hline Height classin $\mathbf{~}$ & Jibat $^{1}$ & Chilimo $^{1}$ & Menagesha $^{1}$ & Wof-Washa $^{1}$ & Denkoro $^{2}$ & Gedo $^{3}$ \\
\hline $6-9$ & 25.5 & 42.1 & 38.5 & 23.3 & 39.3 & 39.47 \\
$9-12$ & 24.0 & 30.8 & 32.0 & 21.3 & 28.3 & 39.87 \\
$12-15$ & 15.2 & 15.3 & 10.8 & 13.7 & 18.9 & 11.59 \\
$15-18$ & 14.0 & 7.5 & 11.0 & 13.1 & 6.7 & 3.69 \\
$18-21$ & 7.2 & 3.4 & 2.2 & 6.1 & 3.2 & 2.00 \\
$21-24$ & 3.7 & $<1$ & 2.2 & 1.6 & 1.7 & 1.51 \\
$24-27$ & 3.5 & - & 1.0 & 8.0 & 1.2 & $<1$ \\
$27-30$ & 2.5 & - & $<1$ & 8.0 & $<1$ & $<1$ \\
$>30$ & 4.3 & - & 2.0 & 4.8 & - & - \\
\hline
\end{tabular}

\section{Vertical Structure}

The vertical structure of trees in Gedo Forest was described following the International Union for Forestry
Research Organization (IUFRO) classification scheme (Lamprecht, 1989). According to the scheme, three vertical structures were distinguished in tropical forests. 
Birhanu Kebede et al.,

These are: upper storey (tree height $>2 / 3$ of top height), middle storey (tree height between $1 / 3$ and $2 / 3$ of top height) and lower storey $(<1 / 3$ of top height). Consequently since the tallest tree in Gedo Forest
Sci. Technol. Arts Res. J., April-June 2014, 3(2):119-131

observed was Prunus africana with $33 \mathrm{~m}$ height, trees in the lower, middle and upper storey were those in the height range $<11 \mathrm{~m}, 11-22 \mathrm{~m}$ and $>22 \mathrm{~m}$ respectively. The description was given in Table 6 .

Table 6: Density, species number and ratios of individuals to species by storey in Gedo forest.

\begin{tabular}{cccccc}
\hline Storey & Density ha $^{-1}(\mathbf{A})$ & Density \% & Species no.(B) & Species \% & Ratio of A to B \\
\hline Lower & 678 & 86.7 & 38 & 97.44 & $17.84: 1$ \\
Middle & 90 & 11.5 & 23 & 58.97 & $3.91: 1$ \\
Upper & 14 & 1.79 & 13 & 33.33 & $1.08: 1$ \\
\hline
\end{tabular}

Almost all woody species were found in the lower storey (97.44\%) and middle storey contains about 23 woody species $(58.97 \%)$, while upper storey was occupied by 13 species of which $27.5 \%$ is covered by Prunus africana. Ficus sur, Ekebergia capensis and Erythrina brucei covered $17.5 \%, 10 \%$, and $7.5 \%$ respectively and four species namely Olea europaea subsp. cuspidata, Olinia rochetiana, Apodytes dimidiata and Syzygium guineese subsp. afromontanum covered $5 \%$ each and the rest four species covered $4 \%$ of the upper layer. The only species in the analysis which does not have a representative from the lower and middle storey is Cordia africana, which shows the plant, has no regeneration status and is highly endangered in the forest. Even in the upper layer its density is very low, this might also indicate that Cordia africana, was probably selectively exploited from Gedo Forest through the past severe exploitation.

Height classes of trees are categorized under the following six figures (Figure 3a-f). The first pattern was formed by the species with the highest density in the first
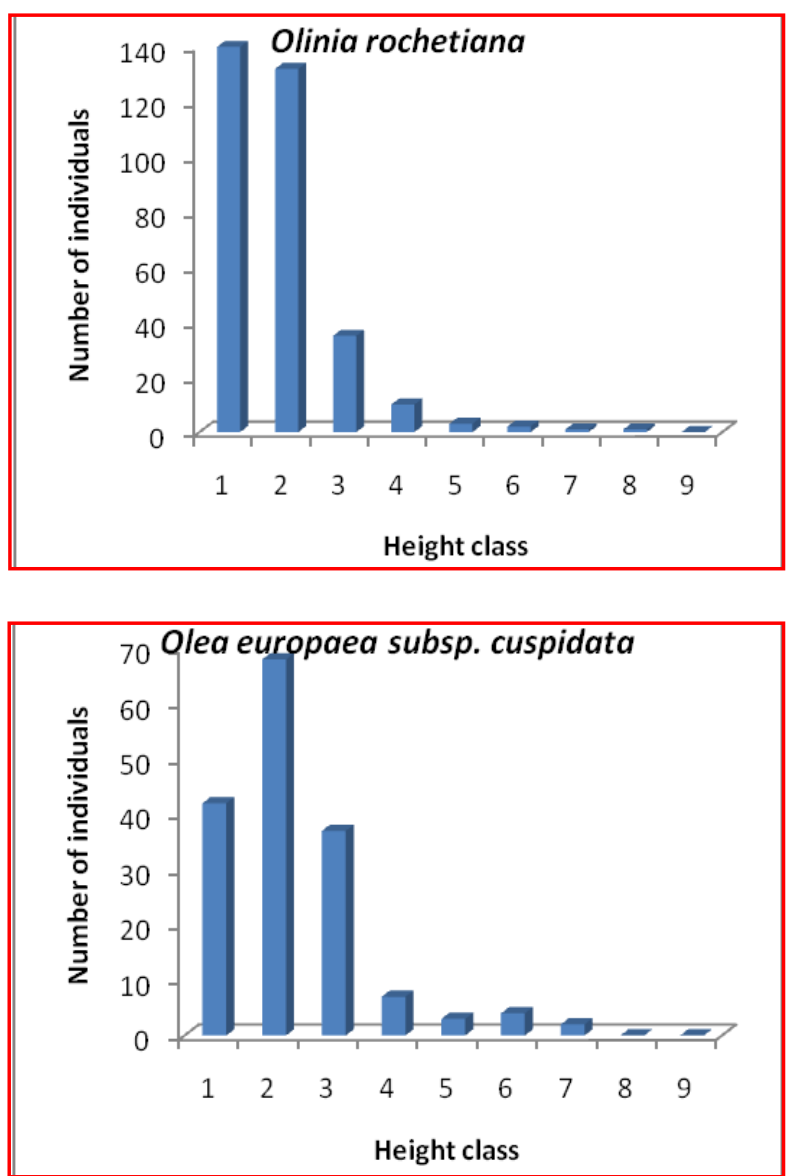

and second class decreasing with increasing height class forming inverted $\mathrm{J}$ shape. Some species in this class include Olinia rochetiana, Olea capensis, Prunus africana and Bersama abyssinica. The second pattern was indicated by the species which have no representative in higher class (Figure $3 b$ ). Some of the species of this class are Teclea nobilis, Chionanthus mildbraedii, Dovyalis abyssinica, Hagenia abyssinica and Dombeya torrida. The third pattern has the highest density in the second class but relatively lower in third class and decreasing towards higher classes. Representative examples are Oleaeuropaea subsp. cuspidata, Allophylus abyssinicus, Apodytes dimidiata and Rhus glutinosa (Figure 3c). The fourth pattern has representative in the whole class with variable densities (Ficus sur type) (Figure 3d). The fifth pattern was formed by few species like Cordia africana (Figure $3 e$ ) which has representative individuals only in class six and seven. The last pattern was formed by the species which have no representative individuals in the first class, in intermediate classes (class 5 and 6 ) and in higher class (class 8). The height class of Erythrina brucei shows these types of pattern (Figure $3 \mathrm{f}$ ).
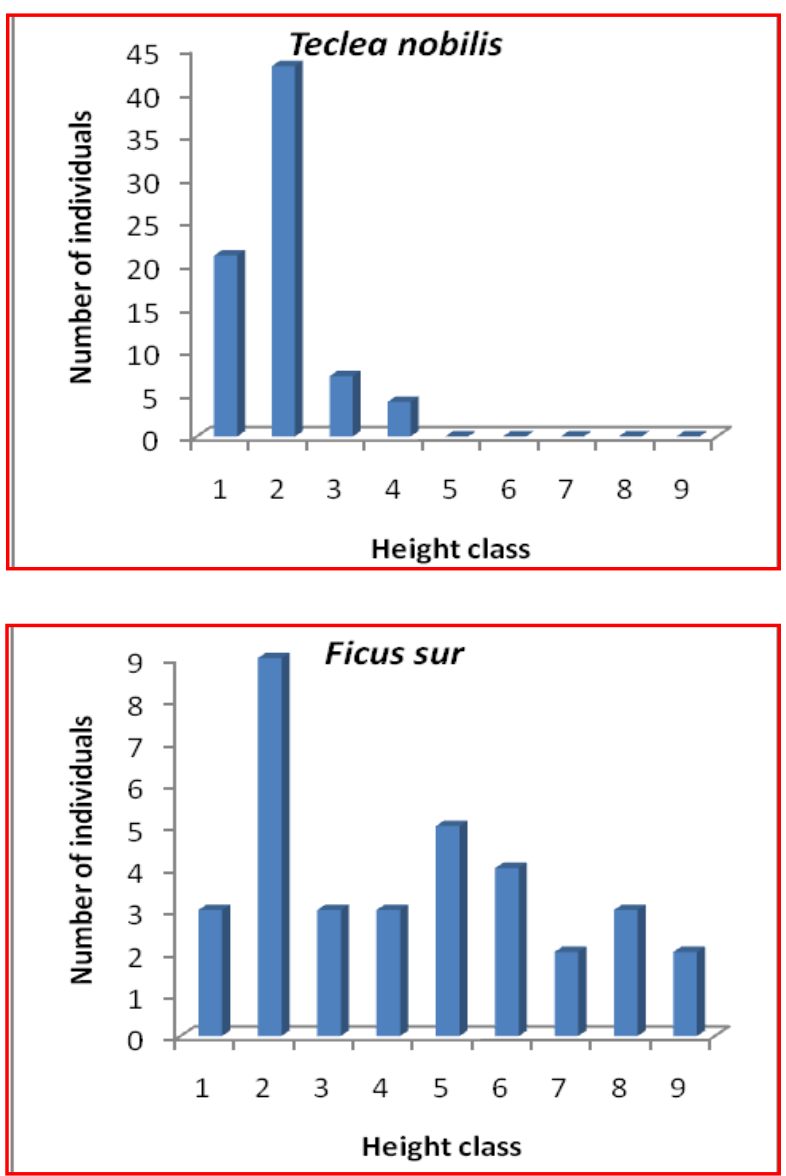

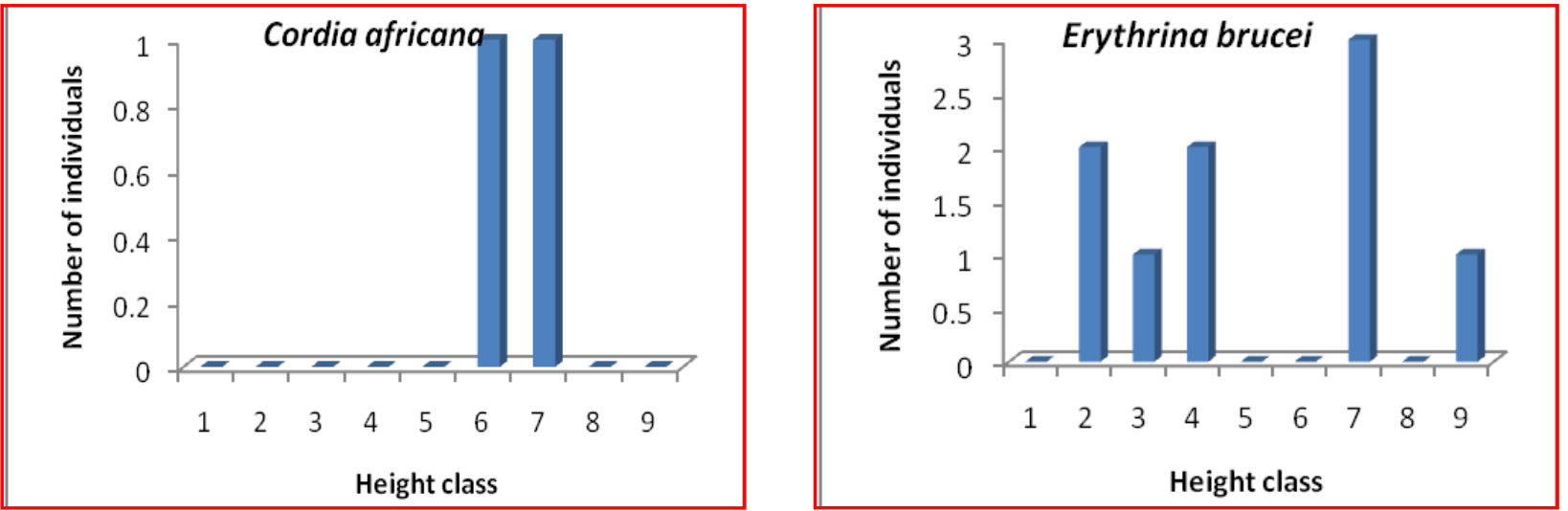

Figure 3 (a-f): Six representative patterns of tree height structures in Gedo Forest Class 1 (3-6), 2 (6-9), 3 (9-12), 4 (1215), 5 (15-18), 6 (18-21), 7 (21-24), 8 (24-27), 9 (>27).

\section{Basal Area}

The total Basal Area of Gedo Forest was $35.45 \mathrm{~m}^{2} \mathrm{ha}^{-1}$. Ficus sur, Podocarpus falcatus, Prunus africana, Olea europaea subsp. cuspidata, Olinia rochetiana and Apodytes dimidiata constitute $61.87 \%$ of total BA in the Gedo Forest. Species like Chionanthus mildbraedii, Bersama abyssinica, Olea capensis subsp. macrocarpa, Brucea antidysenterica and Rhus glutinosa although they have high density; their basal area is not as high as their density. This is due to the nature of the plants not to grow to higher Basal Area. This also indicates that species with the highest basal area do not necessarily have the highest density, indicating size difference between species (Tamrat Bekele, 1994; Simon Shibru and Girma Balcha, 2004; Dereje Denu, 2007).

It was reported that BA provides a better measure of the relative importance of the species than simple stem count (Cain and Castro, 1959; cited in Tamrat Bekele,
1994). Thus, species with the largest contribution to BA can be considered the most important species in the forest. Consequently, the most important tree species in Gedo Forest were Ficus sur, Podocarpus falcatus, Prunus africana, Olea europaea subsp. cuspidata, Olinia rochetiana, Apodytes dimidiata, Ekebergia capensis, Syzygium guineese subsp. afromontanum, Allophylus abyssinicus and Myrica salicifolia. Their BA, density, IVI and frequency values ha- ${ }^{1}$ were in given (Table 7 ).

According to Lamprecht (1989), high density and high frequency coupled with high BA indicate the overall dominant species of the forest. Accordingly, Olinia rochetiana, Olea europaea subsp. cuspidata and Prunus africana are the top three dominant species of the forest since all the three are found in the top five of the ranks of basal area, relative density, relative frequency and IVI per hectare of the ten top dominant species.

Table 7: Basal Area, Relative Density, Relative Frequency and IVI values per hectare of ten top dominant Species of Gedo Forest.

\begin{tabular}{|c|c|c|c|c|}
\hline Species name & BA & RD & RF & IVI \\
\hline Ficus sur & 5.94 & 1.51 & 1.95 & 20.22 \\
\hline Podocarpus falcatus & 4.81 & 2.31 & 3.76 & 19.62 \\
\hline Prunus africana & 3.92 & 6.17 & 5.29 & 22.51 \\
\hline Olea europaea subsp. cuspidata & 3.23 & 7.24 & 6.68 & 23.04 \\
\hline Olinia rochetiana & 2.22 & 14.39 & 8.07 & 29.20 \\
\hline Apodytes dimidiata & 1.82 & 4.04 & 5.07 & 14.87 \\
\hline Ekebergia capensis & 1.73 & 1.20 & 1.53 & 7.62 \\
\hline Syzygium guineese subsp. afromontanum & 1.58 & 5.42 & 4.73 & 14.61 \\
\hline Allophylus abyssinicus & 1.58 & 4.57 & 3.76 & 12.77 \\
\hline Myrica salicifolia & 1.18 & 0.93 & 1.39 & 5.64 \\
\hline
\end{tabular}

Gedo Forest is almost similar to Menagesha Suba Forest, higher than Chilimo Forest and lower than all the other forests under comparisons with respect to basal area per hectare (Table 8). This may be due to variations in the conservation of the forests, exposure to deforestation and geographical location of the forests.

Table 8: Comparison of Gedo Forest, with other 12 afromontane forests in Ethiopia with respect to basal area per hectare (Note: $M A=$ Menna Angetu, $M G=$ Magada, DN = Dindin, MAN = Masha Anderacha, $D K=$ Donkoro, $\mathrm{MN}=$ Menagesha, $\mathrm{CH}=$ Chilimo, $\mathrm{JB}=$ Jibat, $\mathrm{WW}=$ Wof - Washa, $\mathrm{DD}=$ Dodolla, $\mathrm{BF}=$ Bibita Forest (Gura Ferda,), EG=Egdu (MAM), GD= Gedo Forest).

\begin{tabular}{rrrrrrrrrrrrrr}
\hline Forest & ${ }^{2} \mathbf{M G}$ & ${ }^{1} \mathbf{M N}$ & ${ }^{3} \mathrm{DN}$ & ${ }^{4}$ DK & ${ }^{5}$ MAN & ${ }^{6}$ MA & ${ }^{1} \mathbf{C H}$ & ${ }^{1}$ JB & ${ }^{1}$ WW & ${ }^{7}$ DD & ${ }^{8}$ BF & ${ }^{9}$ EG & ${ }^{10}$ GD \\
\hline BA ha $^{-1}$ & 68.52 & 36.1 & 49.0 & 45.0 & 81.90 & 94.22 & 30.1 & 47.5 & 101.8 & 129.0 & 69.9 & 84.17 & 35.45
\end{tabular}

Source: ${ }^{1}$ Tamrat Bekele (1993), ${ }^{2}$ Genene Bekele (2005), ${ }^{3}$ Simon Shibru and Girma Balcha (2004), ${ }^{4}$ Abate Ayalew et al., (2006), ${ }^{5}$ Kumilachew Yeshitela and Taye Bekele (2003), ${ }^{6}$ Ermias Lulekal et al., (2008), ${ }^{7}$ Kitessa Hundera (2003), ${ }^{8}$ Dereje Denu (2007), ${ }^{9}$ Abiyou Tilahun (2009), ${ }^{10}$ The present study 
Birhanu Kebede et al.,

\section{Frequency}

Frequency is the number of quadrats in which a given species occurred in the study area. Frequency is the indication of homogeneity and heterogeneity of given vegetation in which the higher number of species in higher frequency classes and low number of species in lower frequency classes show similar species composition while large number of species in lower frequency classes and small number of species in higher frequency classes indicates higher heterogeneity (Lambrecht, 1989). The frequency of all the tree species in this Forest is given in Table 17 . The three most frequently observed species are Olinia rochetiana 58 times out of 72 quadrats possessing $80.56 \%$ occurrence and 8.07 relative frequencies. The second and the third were Bersama abyssinica with 79.17 $\%$ occurrence and 7.73 relative frequencies and Olea europaea subsp. cuspidata was with $66.67 \%$ occurrence and 6.68 relative frequencies. The ten least occurred species were Hagenia abyssinica, Dombeya torrida, Millettia ferruginea subsp. ferruginea, Erythrina brucei, Syzygium guineense subsp. guineense, Schrebera alata, Juniperus procera, Cordia africana, Pittosporum viridiflorum and Celtis africana, eachconstituting less than 1 relative frequency and a total of 3.62 relative frequencies.

\section{Importance Value Index (IVI)}

Importance Value Index combines data from three parameters which include RF, RD and RDO (Kent and Coker, 1992). It is crucial to compare the ecological
Sci. Technol. Arts Res. J., April-June 2014, 3(2):119-131

significance of species (Lamprecht, 1989). It was also stated that species with the greatest importance value are the leading dominant of specified vegetation (Simon Shibru and Girma Balcha, 2004). Accordingly, the 10 leading dominant and ecologically most significant trees in Gedo Forest are Olinia rochetiana, Olea europaea subsp. cuspidata, Prunus africana, Ficus sur, Podocarpus falcatus, Bersama abyssinica, Syzygium guineese subsp. afromontanum, Chionanthus mildbraedii, Allophylus abyssinicus and Myrica salicifolia. They contribute 185.86 $(61.98 \%)$ from a total of 299.85 IVI value. The reason why they have higher IVI value is that they have higher relative density, relative frequency and relative abundance relative to other species in the forest. Tree species, their IVI and priority for conservation is given in Table 10 in decreasing order of IVI values. The leading dominant and ecologically most significant species might also be the most successful species in regeneration, pathogen resistance, preference by browsing animals (least preferred), attraction of pollinators and attraction of seed predators that facilitate seed dispersal within the existing environmental conditions (Fufa Kenea, 2008).

Priority for conservation of these species should be given based on their IVI values. i.e. the first priority for species with least IVI value and the last priority of conservation for species with highest IVI values. Concerning the IVI species that grouped under class 4 (Table 9) should get the uppermost conservation priority because these are at risk of local extinction.

Table 9:List of species under each IVI class

\begin{tabular}{|c|c|}
\hline Class 1 & Class 3 \\
\hline Olinia rochetiana & Maytenus arbutifolia \\
\hline Olea europaea subsp. cuspidata & Teclea nobilis \\
\hline Prunus africana & Olea capensis subsp. macrocarpa \\
\hline \multirow[t]{5}{*}{ Ficus sur } & Ekebergia capensis \\
\hline & Scolopia theifolia \\
\hline & Class 3 \\
\hline & Brucea antidysenterica \\
\hline & Rhus vulgaris \\
\hline Class 2 & Myrica salicifolia \\
\hline Podocarpus falcatus & Calpurnia aurea \\
\hline Bersama abyssinica & Maesa lanceolata \\
\hline Apodytes dimidiata & Nuxia congesta \\
\hline Syzygium guineese subsp. afromontanum & Croton macrostachyus \\
\hline Chionanthus mildbraedii & Albizia schimperiana \\
\hline Allophylus abyssinicus & Dovyalis abyssinica \\
\hline \multirow[t]{3}{*}{ Rhus glutinosa } & Rhamnus staddo \\
\hline & Acacia abyssinica \\
\hline & Gnidia glauca \\
\hline Class 4 & Buddleja polystachya \\
\hline Syzygium guineense subsp. guineense & Hagenia abyssinica \\
\hline Schrebera alata & Millettia ferruginea subsp. ferruginea \\
\hline Pittosporum viridiflorum & Erythrina brucei \\
\hline Juniperus procera & Dombeya torrida \\
\hline Celtis africana & Cordia africana \\
\hline
\end{tabular}


Table 10: The importance value index (IVI) and priority class for conservation of tree species in Gedo Forest (RD = Relative density, $\mathrm{RDO}=$ Relative Dominance, $\mathrm{RF}=$ Relative frequency).

\begin{tabular}{|c|c|c|c|c|c|c|c|}
\hline & Scientific name & RD & RDO & RF & IVI & IVI\% & Priority \\
\hline 1 & Olinia rochetiana & 14.39 & 6.74 & 8.07 & 29.20 & 9.74 & 4 \\
\hline 2 & Olea europaea subsp.cuspidata & 7.24 & 9.12 & 6.68 & 23.04 & 7.68 & 4 \\
\hline 3 & Prunus africana & 6.17 & 11.05 & 5.29 & 22.51 & 7.51 & 4 \\
\hline 4 & Ficus sur & 1.51 & 16.77 & 1.95 & 20.22 & 6.75 & 4 \\
\hline 5 & Podocarpus falcatus & 2.31 & 13.55 & 3.76 & 19.62 & 6.54 & 3 \\
\hline 6 & Bersama abyssinica & 6.39 & 1.46 & 7.93 & 15.79 & 5.26 & 3 \\
\hline 7 & Apodytes dimidiata & 4.04 & 5.12 & 5.70 & 14.87 & 4.96 & 3 \\
\hline 8 & Syzygium guineese subsp. afromontanum & 5.42 & 4.47 & 4.73 & 14.61 & 4.87 & 3 \\
\hline 9 & Chionanthus mildbraedii & 7.68 & 1.39 & 4.17 & 13.24 & 4.42 & 3 \\
\hline 10 & Allophylus abyssinicus & 4.57 & 4.45 & 3.76 & 12.77 & 4.26 & 3 \\
\hline 11 & Rhus glutinosa & 4.17 & 2.15 & 3.76 & 10.08 & 3.36 & 3 \\
\hline 12 & Maytenus arbutifolia & 3.15 & 2.26 & 3.76 & 9.17 & 3.06 & 2 \\
\hline 13 & Teclea nobilis & 3.64 & 1.35 & 3.76 & 8.75 & 2.92 & 2 \\
\hline 14 & Olea capensis subsp. macrocarpa & 2.58 & 2.67 & 2.50 & 7.75 & 2.58 & 2 \\
\hline 15 & Ekebergia capensis & 1.20 & 4.89 & 1.53 & 7.62 & 2.54 & 2 \\
\hline 16 & Scolopia theifolia & 2.71 & 1.52 & 2.50 & 6.74 & 2.25 & 2 \\
\hline 17 & Brucea antidysenterica & 2.58 & 0.09 & 4.03 & 6.70 & 2.23 & 2 \\
\hline 18 & Rhus vulgaris & 2.44 & 0.36 & 3.06 & 5.86 & 1.95 & 2 \\
\hline 19 & Myrica salicifolia & 0.93 & 3.32 & 1.39 & 5.64 & 1.88 & 2 \\
\hline 20 & Calpurnia aurea & 2.40 & 0.11 & 2.78 & 5.29 & 1.76 & 2 \\
\hline 21 & Maesa lanceolata & 1.78 & 0.22 & 2.64 & 4.63 & 1.55 & 2 \\
\hline 22 & Nuxia congesta & 1.82 & 0.22 & 1.95 & 3.99 & 1.33 & 2 \\
\hline 23 & Croton macrostachyus & 1.29 & 0.87 & 1.67 & 3.83 & 1.28 & 2 \\
\hline 24 & Albizia schimperiana & 1.02 & 0.96 & 1.39 & 3.37 & 1.12 & 2 \\
\hline 25 & Dovyalis abyssinica & 1.11 & 0.57 & 1.67 & 3.35 & 1.12 & 2 \\
\hline 26 & Rhamnus staddo & 1.15 & 0.02 & 1.95 & 3.13 & 1.04 & 2 \\
\hline 27 & Acacia abyssinica & 1.02 & 0.71 & 1.25 & 2.98 & 1.00 & 2 \\
\hline 28 & Gnidia glauca & 1.20 & 0.26 & 1.39 & 2.85 & 0.95 & 2 \\
\hline 29 & Buddleja polystachya & 0.89 & 0.33 & 1.25 & 2.47 & 0.82 & 2 \\
\hline 30 & Hagenia abyssinica & 0.93 & 0.29 & 0.70 & 1.92 & 0.64 & 2 \\
\hline 31 & Millettia ferruginea subsp. ferruginea & 0.40 & 0.96 & 0.56 & 1.91 & 0.64 & 2 \\
\hline 32 & Erythrina brucei & 0.36 & 0.71 & 0.28 & 1.34 & 0.45 & 2 \\
\hline 33 & Dombeya torrida & 0.40 & 0.15 & 0.70 & 1.25 & 0.42 & 2 \\
\hline 34 & Cordia africana & 0.09 & 0.72 & 0.28 & 1.09 & 0.36 & 2 \\
\hline 35 & Syzygium guineense subsp. guineense & 0.27 & 0.07 & 0.28 & 0.61 & 0.20 & 1 \\
\hline 36 & Schrebera alata & 0.22 & 0.02 & 0.28 & 0.52 & 0.17 & 1 \\
\hline 37 & Pittosporum viridiflorum & 0.27 & 0.06 & 0.14 & 0.47 & 0.16 & 1 \\
\hline 38 & Juniperus procera & 0.13 & 0.02 & 0.28 & 0.43 & 0.14 & 1 \\
\hline \multirow[t]{2}{*}{39} & Celtis africana & 0.13 & 0.00 & 0.14 & 0.27 & 0.09 & 1 \\
\hline & Total & 100.00 & 100.00 & 100.00 & 299.85 & 100.00 & \\
\hline
\end{tabular}

\section{Population Structure forSelected Woody Species}

Population structures of trees have significant implications to their management, sustainable use and conservation (Simon Shibru and Girma Balcha, 2004). The analysis of population structure of selected woody species resulted in six different patterns (Figure $4 \mathrm{a}-\mathrm{f}$ ) and represented by one species from the group.

The first pattern was formed by the species having high number of individuals in the second class and relatively lowers in first and third class then decrease with increasing $\mathrm{DBH}$ towards the higher classes (Figure 4a). The species in this group are Olinia rochetiana,Syzygium guineense subsp. afromontanum, Rhus glutinosa, Croton macrostachyus, Maytenus arbutifolia, Olea capensis and Scolopia theifolia. The second pattern contains high number of individuals in the first and third DBH classes, medium in the second class, decreasing in the fourth and fifth classes and none in the rest DBH classes (Figure 4b).
These species contain good regeneration status but less recruitment. Species which show this pattern are Teclea nobilis, Hagenia abyssinica, Rhus vulgaris, Dovyalis abyssinica, Gnidia gluca and Nuxia congesta. The third pattern is inverted $\mathrm{J}$-shape in which species have good reproduction and recruitment. Species exhibiting this normal diameter class distribution were Acacia abyssinica (Figure 4c), Chionanthus mildbraedii, Olea europaea subsp. cuspidata, Allophylus abssinicus, Albizia schimperiana and Podocarpus falcatus.

The species in the fourth pattern were restricted to DBH class of 1,2 and 3 (Figure $4 d$ ). They didn't have individuals in the higher DBH classes some of them due to the nature of the species (they do not grow to higher $\mathrm{DBH}$ class e.g. Brucea antidysenterica) and some of them due to removal of the plant for different activities. The species which show this pattern were Brucea antidysenterica, Syzygium guineense subsp. guineense, 
Birhanu Kebede et al.,

Pittosporum viridiflorum, Celtis africana, Millettia ferruginea subsp. ferruginea, Juniperus procera, Maesa lanceolata and Rhamnus staddo. The fifth pattern shows up and down (decrease to some extent with increasing DBH class then increase in the next class and continue like this covering the whole DBH classes). There may be selective cutting of the trees in the different DBH classes for domestic use (Figure 4e). The species in this group include Ekebergia capensis,Apodytes dimidiata, Ficus sur
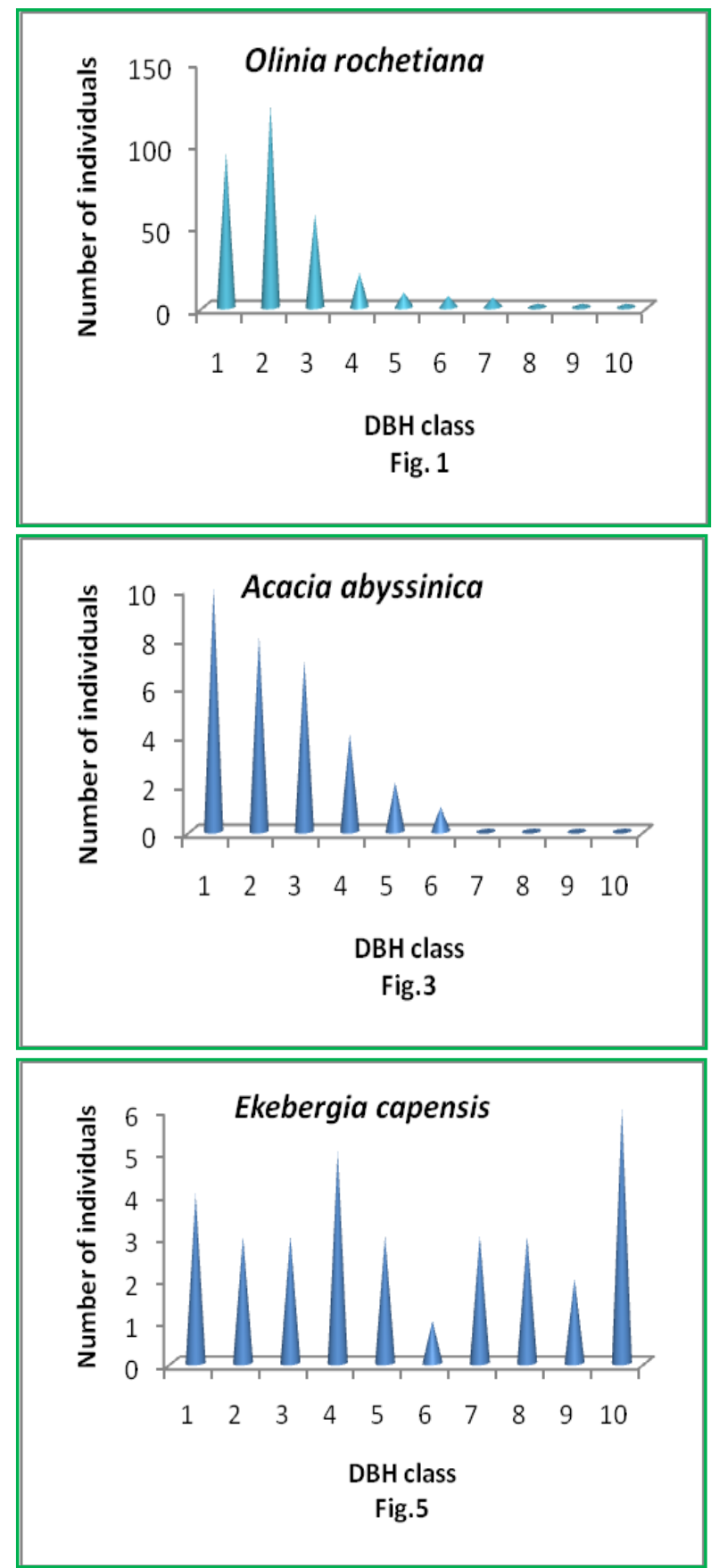

Sci. Technol. Arts Res. J., April-June 2014, 3(2):119-131

and Prunus africana. In the last pattern, (Figure 4f) there were no individuals in the first DBH class $(2-8 \mathrm{~cm})$, may be due to low regeneration status of the species and removal of the young individuals of the species for construction materials like for making bee hives as well as browsing by domestic animals. They also have few or no representative individuals in higher DBH classes. The species in this class include Dombeya torrida, Cordia africana
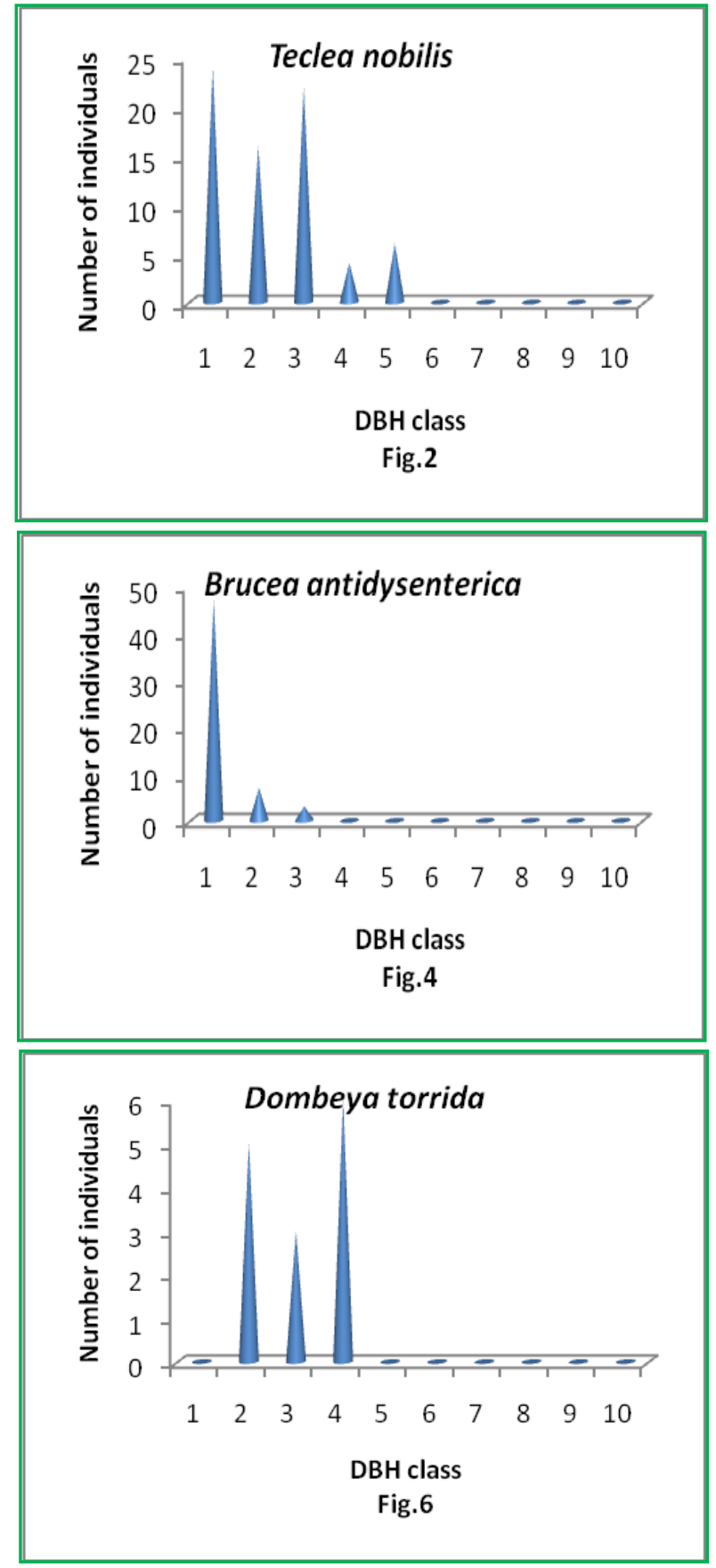

Figure 4 (a-f): Six representative patterns of tree species population structures in Gedo Forest where DBH classes are: 1) $2-8 \mathrm{~cm}, 2) 8-14 \mathrm{~cm}, 3) 14-20 \mathrm{~cm}, 4) 20-26 \mathrm{~cm}, 5) 26-32 \mathrm{~cm} \mathrm{6)} 32-38 \mathrm{~cm}, 7) 38-44 \mathrm{~cm}, 8) 44-50 \mathrm{~cm}, 9)$ $50-56 \mathrm{~cm}, 10)>56 \mathrm{~cm}$.

\section{Regeneration Status of Gedo Forest}

Composition and density of seedlings and saplings would indicate the regeneration status of that forest. The composition and density of seedlings and saplings of tree species in Gedo Forest were included in this study.
The total density of seedlings, saplings and trees were 1068.21, 837.51 and 738.55 ha ${ }^{-1}$ respectively (Figure 5). 


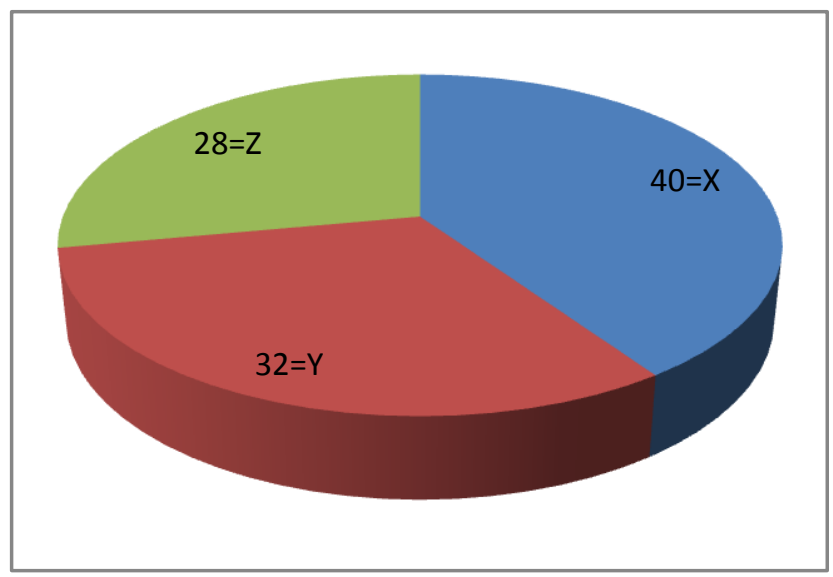

Figure 5: Density percentage of seedlings $(X)$, saplings $(Y)$ and mature $(Z)$ of tree and shrub species in the study area.

The ratio of seedlings to saplings was 1.3 , seedlings to mature trees was 1.5 and saplings to mature trees was 1.1. These shows that the distribution of seedlings as a whole is greater than that of saplings and mature trees and that of saplings is greater than mature trees.

The composition, distribution and density of seedlings and saplings indicate the future status of the forest.
Coming to the conservation priorities, the tree species in group one whose seedlings are absent (Table 11) should be given the first priority for conservation because they are at higher risk of local extinction and some of them are included in national priority species list and also have commercial importance for economic development of the country.

Table 11: Regeneration status of some tree species in Gedo Forest

\begin{tabular}{lll}
\hline Group 1 & & Group 2 \\
\hline Species list & & Species list \\
\hline Olinia rochetiana & Nuxia congesta & Syzyium guineense subsp. guineense \\
Calpurnia aurea & Croton macrostachyus & Pittosporum viridiflorum \\
Bersama abyssinica & Rhamnus staddo & Celtis africana \\
Olea europaea subsp. cuspidata & Scolopia theifolia & Cordia africana \\
Chionanthus mildbraedii & Gnidia glauca & \\
Prunus africana & Ekebergia capensis & \\
Syzygium guineense subsp. afromontanumea & \\
Rhus glutinosa & Acacia abyssinica & \\
Apodytes dimidiata & Myrica salicifolia & \\
Podocarpus falcatus & Dovyalis abyssinica & \\
Teclea nobilis & Albizia schimperiana & \\
Rhus vulgaris & Buddleja polystachya & \\
Brucea antidysenterica & Schrebera alata & \\
Allophylus abyssinicus & Erythrina brucei & \\
Maytenus arbutifolia & Dombeya torrida & \\
Ficus sur & Juniperus procera & \\
Maesa lanceolata & Olea capensis subsp. macrocarpa & \\
\hline
\end{tabular}

\section{CONCLUSIONS}

Variability in population structure, which implies vegetation dynamic, was recognized from the analysis of tree species $\mathrm{DBH}$. In addition, density class description of the forest indicated the dominance of small sized individuals asserting Gedo Forest is in a stage of secondary development. Some economically and ecologically important species had population structures that showed abnormal recruitment patterns with poor reproduction, where, Cordia africana and Celtis africana are examples. Therefore, there is a need to develop and implement effective management systems in the area to facilitate optimal regeneration that assures the sustainable use of these species at present and in the future. Moreover, on the basis of species population structures, IVI and regeneration status, the tree species of Gedo Forest were objectively prioritized for conservation. Among them Cordia africana, Celtis africana, Syzygium guineense subsp. guineense and Schrebera alata should get the uppermost conservation priority.

The density of woody species in Gedo Forest decreases with increasing height classes. The Forest is characterized by high density of trees in the lower class than in the higher. Thus, the forest is in good state of recruitment. Three layers (lower, middle and upper) of tree canopies were identified from the study of vertical stratification of Gedo Forest. Almost all woody species were found in the lower storey $(97.44 \%)$ and middle storey contains about 23 woody species (58.97\%), while upper storey was occupied by 13 woody species of which $27.5 \%$ is covered by Prunus africana. Ficus sur, Ekebergia capensis, Erythrina brucei covered 17.5\%, $10 \%$, and $7.5 \%$ respectively and four species namely 
Birhanu Kebede et al.,

Olea europaea subsp. cuspidata, Olinia rochetiana, Apodytes dimidiata and Syzygium guineese subsp. afromontanum covered $5 \%$ each and the rest four species covered $4 \%$ of the upper layer.

Forests regulate microclimate, protect water resources, provide forest products and are homes to plant and animal species. Therefore, it is must to protect and pass to the next generation. In the area where this study has been conducted cattle are putting heavy pressure on the forest. Shrubs as well as trees are cut for fuel and timber frequently. Animal rearing in the forest and timber cutting from the forest should be stopped if possible or at least controlled by the concerned body.

It is essential to create awareness among the local community about forest conservation and wise utilization. Extension program including forest management should be extended so as to increase awareness on people for wise utilization of the forest. One of the major threats to the forest vegetation is expansion of farmland surrounding the forest and illegal logging. To reduce this and use the forest sustainably, participatory forest management can be used as an alternative.

\section{REFERENCES}

Abate Ayalew, Tamrat Bekele and Sebsebe Demissew. (2006). The Undifferentiated afromontane forest of Denkoro in the central highland of Ethiopia: A floristic and Structural Analysis. SINET: Ethiopian Journal of Sciences 29(1): 45-56.

Abiyou Tilahun (2009). Floristic composition and structure of vegetation in Menagesha Amba Mariam Forest in Central highlands of Ethiopia. Unpublished M.Sc. Thesis, Addis Ababa University, Addis Ababa.

Adugna Feyissa, Teshome Soromessa and Mekuria Argaw (2013). Forest Carbon Stocks and Variations along Altitudinal Gradients in Egdu Forest: Implications of Managing Forests for Climate Change Mitigation. Science, Technology and Arts Research Journal 2(4): 4046.

Demel Teketay. (1992). Human impact on a natural montane forest in southeastern Ethiopia. Mountain Research and Development 12: 393-400.

Dereje Denu. (2007). Floristic composition and Ecological Study of Bibita Forest (Gura Ferda), Southwest Ethiopia. M.Sc. Thesis, Addis Ababa University, Addis Ababa.

EFAP (1994). Ethiopian Forestry Action Program, Volume III. The Challenge for Development. Ministry of Natural Resources, Addis Ababa.

Endalew Amenu (2007). Use and management of medicinal plants by indigenous people of Ejaji area Cheliya Woreda) West Shoa, Ethiopia: an ethnobotanical approach. M.Sc. Thesis, Addis Ababa University, Addis Ababa.

Ensermu Kelbessa, Sebsebe Demissew, Zerihun Woldu and Edwards, S. (1992). Somethreatened Endemic plants of Ethiopia. In: (Edwards, S. and Zemede Asfaw eds.) The status of some plants in parts of tropical Africa. Pp. 35-55. NAPRECA, No.2 Botany2000: East and Central Africa.

Ensermu Kelbessa and Teshome Soromessa (2008). Interfaces of regeneration, structure, diversity and use of some plant species in Bonga forest: A reservoir for wild coffee gene pool. SINET: Ethiopian Journal of Science 31(2): 121-134.
Sci. Technol. Arts Res. J., April-June 2014, 3(2):119-131

Ensermu Kelbessa (Unpublished). List of endemic flowering plants of Ethiopia. Addis Ababa University, Ethiopia.

Ermias Lulekal., Ensermu Kelbessa., Tamrat Bekele and Haile Yineger. (2008). PLANT Species Composition and Structure of The Mana Angetu Moist Montane Forest, South-Eastern Ethiopia. Journal of East African Natural History 97(2): 165-185.

EWNHS (1996). Important Bird Areas of Ethiopia. A First Inventory, Ethiopian Wildlife and Natural History Society, Addis Ababa.

Fekadu Gurmessa, Teshome Soromessa and Ensermu Kelbessa (2011). Florisitc Composition and Community analysis of Komto Afromontane Moist Forest of East Wellega, West Ethiopia. Science, Technology and Arts Research Journal 2(2): 58-69.

Fekadu Gurmessa, Teshome Soromessa and Ensermu Kelbessa (2012). Structure and Regeneration status of Komto Afromontane Moist forest, East Wellega Zone, West Ethiopia. Journal of Forestry Research 23 (2): 205216.

Feyera Senbeta (2006). Biodiversity and Ecology of Afromontane Rainforests with Wild Coffea arabica L. Populations in Ethiopia. Ecology and Development Series No. 38. Center for Development Research, University of Bonn.

Fufa Kenea (2008). Remnant Vegetation and Population Struture of Woody Species of Jima Forest, Western Ethiopia. Unpublished M.Sc. Thesis, Addis Ababa University, Addis Ababa.

Genene Bekele (2005). Floristic composition and structure of the vegetation of Magada forest, Borana zone, Oromia National Regional State. Unpublished M.Sc. Thesis, Addis Ababa University, Addis Ababa.

Kent, M. and Coker, P. (1992). Vegetation Description and Analysis. A practical approach. John Wiley and Sons, New York, 363p.

Kitessa Hundera (2003). Floristic composition and structure of the Dodolla forest, Bale zone, Oromia Regional State. M.Sc thesis, Addis Ababa University, Addis Ababa.

Kumilachew Yeshitela and Taye Bekele (2003). The woody species composition and structure of MashaAndederacha forest, southwestern Ethiopia. Ethiopian Journal of Biological Sciences 2: 31-48.

Lamprecht, H. (1989). Silverculture in the Tropics. Tropical Forest Ecosystems and their Tree Species-Possibilities and Methods for their Long-term Utilization. T2 Verlagsgesellschaft $\mathrm{GmbH}$, RoBdort, Germany.

Simon Shibru and Girma Balcha (2004). Composition, Structure and regeneration status of woody species in Dindin Natural Forest, Southeast Ethiopia: An implication for conservation. Journal of Biological Sciences(1)3:1535.

Tadesse Woldemariam (2003). Vegetation of the Yayu forest in Southwest Ethiopia: Impacts of human use and Implications for In situ conservation of Wild Coffea arabica L. populations. Ecology and Development Series No.10. Center for Development Research, University of Bonn.

Tamrat Bekele (1993). Vegetation ecology of Afromontane forests on the central plateau ofShewa, Ethiopia. Acta Phytogeographica Suecica 79:1-59. 
Birhanu Kebede et alo,

Tamrat Bekele (1994). Studies on remnant Afromontane forests on the central plateau of Shewa, Ethiopia. Ph.D. Thesis. Uppsala University, Sweden. Pp.59.

Teshome Soromessa., Demel Teketay and Sebsebe Demissew. (2004). Ecological study of the vegetation in Gamo Gofa zone, Southern Ethiopia. Tropical Ecology 45(2): 209-221.

Teshome Soromessa, Ensermu Kelbessa, Afework Bekele, Getinet Masresha, Desalegn Ejigu, Melese Yihune and Fisseha Itanna (2011). Current Status and Significance of Faunal and Floral Diversity of the Simien Mountains, Northern Ethiopia. A poster presented on December 3031, 2011 during the conference on Thematic Research Organized by Addis Ababa University, Addis Ababa, Ethiopia.

Teshome Soromessa (2013). Ecological Phytogeography: A Case Study of Commiphora Species. Science, Technology and Arts Research Journal 2(3): 93-104.

Teshome Soromessa and Ensermu Kelbessa (2013a). Diversity, Ecology and Regeneration Studies of Bonga, Borana and Chilimo Forests of Ethiopia. Lambert Academic Publishing, Saarbrücken, Germany, Pp 140, ISBN 978-3-659-41509-8.
Sci. Technol. Arts Res. J., April-June 2014, 3(2):119-131

Teshome Soromessa and Ensermu Kelbessa (2013b). Diversity and Endemicity of Chilimo Forest, Central Ethiopia. Bioscience Discovery 4(1): 1-4.

Teshome Soromessa and Ensermu Kelbessa (2014). Interplay of regeneration, structure and uses of some woody species in Chilimo Forest, Central Ethiopia. Science, Technology and Arts Research Journal 3(1): 90100.

van der Maarel, E. (1979). Transformation of cover abundance values and its effects on community similarity. Vegetation 39:97-114.

Woldeyohannes Enkossa (2008). Floristic Analysis of Alata Bolale Forest in Gudaya Bila Wereda East Welega Zone, Oromia Regional State, West Ethiopia. Unpublished M.Sc Thesis, Addis Ababa University, Addis Ababa.

Zerihun Woldu (1999). Forests in the vegetation types of Ethiopia and their status in the geographical context. In: Forest Genetic Resources Conservation: Principles, Strategies and Actions, (Edwards, S., Abebe Demissie, Taye Bekele and Haase, G., eds). Workshop Proceedings. Institute of Biodiversity Conservation and Research, and GTZ, Addis Ababa. Pp. 1-38. 